\title{
Dashboard application model in supplier evaluation by using artificial immune system and data mining methods
}

\author{
Yapay bağışıklık sistemi ve veri madenciliği yöntemlerini kullanarak \\ tedarikçi değerlendirmede gösterge paneli uygulama modeli
}

\author{
Yüksel YURTAY1* iD, Murat AYANOĞLU2 iD \\ ${ }^{1}$ Computer Engineering Department, Faculty of Computer and Information Sciences, Sakarya University, Sakarya, Turkey \\ yyurtay@sakarya.edu.tr \\ ${ }^{2}$ Production Management and Marketing Department, Sakarya Business School, Sakarya University, Sakarya, Turkey. \\ ayan@sakarya.edu.tr
}

\begin{abstract}
Globalization and rapid developments in science and technology lead to an increase in competition and diffraction in the objectives in the production methods. In order to meet the rapidly changing and differentiated needs, manufacturing businesses are left against technological renewal. Especially usage of the data that is collected in electronic media and the ease of access to information forces businesses to review computer systems on point of production management. Visualization of the data analyzed in the databases is a suitable solution in the decision-making processes of the manufacturing companies. In this context, the dashboard is seen as a good support tool especially for the manufacturing businesses, at a fast and accurate decision-making point. This article represents a new model approach to accumulated analysis and its sharing for the manufacturing businesses by using the artificial immune system and data mining techniques under the title of the dashboard. In the model, data is increased and handled with clonal selection algorithm. In the analysis stage, the data is clustered with $k$ means algorithm. The data are visualized by calculating the weighted average and the performance indicators. The visuals that have been obtained will be shared with an app which supports the decision makers with the dashboard rules. Our approach provides a new approaching model to unite, analyze and visualize the collections of data.
\end{abstract}

Keywords: Dashboard, Supply chain management, Data mining, Artificial immune system.

\section{Introduction}

Rapid developments in information and communication technologies force decision support systems to review and change. The developments also led to the differentiation and deepening of the information needed. Today, production management systems need change and development. Production systems like this and similar ones are focusing on the data regarding the continuity of the operational processes. However, today's businesses require the sharing of the data that is instant, correct and analyzed on operational, tactical and strategic levels.

The need for information and data analyses paved the way for new searches. Complete integration of information technologies to the supply chain is considered to be one of the most important issues. Planning of the strategic information

\section{Öz}

Küreselleșme, bilim ve teknolojideki hızlı gelișmeler, rekabetin artmasına, üretim yöntemlerindeki amaçların farklllașmasına neden olmaktadır. Hızla değişen ve farklılaşan ihtiyaçların karşılanabilmesi, üretim yapan isletmeleri, teknolojik olarak yenilenmek ile karșı karșıya bırakmıștır. Özellikle elektronik ortamlarda biriken verinin kullanımı ve bilgiye erișimin kolaylașması, ișletmeleri, bilgisayar sistemleri ve üretim yönetimi noktasında gözden geçirmeye zorlamaktadır. Üretim yapan işletmelerin karar alma süreçlerinde, ihtiyaç duyulan bilgiyi karşılayabilmesi için, veri tabanlarında analiz edilen verilerin görselleștirilmesi, uygun bir çözüm olarak ortaya çıkmaktadır. Bu bağlamda gösterge paneli, özellikle üretim yapan ișletmeler için, hızl ve doğru karar alma noktasında, iyi bir destek aracı olarak görülmektedir. Bu makale, gösterge paneli bașlığı altında, yapay bağışıklık sistemi ve veri madenciliği tekniklerini kullanarak, üretim yapan ișletmelerde biriken verilerin analizi ve paylașımı için, yeni bir model yaklașımı sunar. Modelde, klonal seçim algoritması ile veriler çoğaltılır ve eğitilir. Analiz așamasında k-means algoritması ile veriler kümelenir. Ağırlıklı ortalama ile performans göstergeleri hesaplanarak, veriler görselleştirilir. Elde edilen görseller, gösterge paneli kuralları ile karar vericilere destek olan, bir uygulama ile paylaștırllır. Yaklașımımız, veri koleksiyonları birleștirmek, çözümlemek ve görselleștirmek için yeni bir yaklașım modeli sunar

Anahtar kelimeler: Gösterge paneli, Tedarik zinciri yönetimi, Veri madenciliği, Yapay bağıșıklık sistemi. system is different from the requirements of the classical businesses. Nowadays, the supply chain management information system framework must include its strategic objectives. The support of the top management is very essential in changing the available supply chain to ever-changing requirements of the clients. In addition, in-house communication, communication types between the departments and participation of the suppliers are the decisive points of an efficient supply chain [1].

In recent years, the importance of the integration between the supplier, manufacturer and customer has been increasing. Effective integration of suppliers with the supply chain is one of the essential factors in increasing the competitiveness of the enterprise. A well-designed supply chain integration can dramatically increase product quality and productivity and ultimately increase customer satisfaction and profitability [2].

${ }^{*}$ Corresponding author/Yazışılan Yazar 
One of the most important tools of recent times to ensure the integration of the supply chain is the dashboard. Managers and business owners want to be able to easily see the areas of improvement, instant process information, ricks and trends in real-time. With its increasing interest, the dashboard meets an essential need at this point.

Dashboard: Basically, the concept of term dashboard is inspired by and created from the dashboards in automobiles and airplanes [3]. Dashboards are digitally designed and their usage is increasing in every area. In today's world, digital dashboards have started to include scientific approaches and solutions in the area of business intelligence [4]. On a broad level, digital dashboards provide users with ease of use to monitor, analyze and optimize crucial business actions by enabling users at each level of the hierarchy to improve the decisions of the users [5].

Dashboards provide a simple front face for complex data while supporting the correct decision-making processes of the managers. At the same time, they are sophisticated software applications that are presented to users in a simple, fast and complete way which interprets the operational data with new scientific and technological approaches. With the increase in competition, the interest in the instrument panel has increased. Increasing dashboard research and providers is a good indicator. In Figure 1 the change in number of the articles that the word "dashboard" is used in the title over the years can be seen.

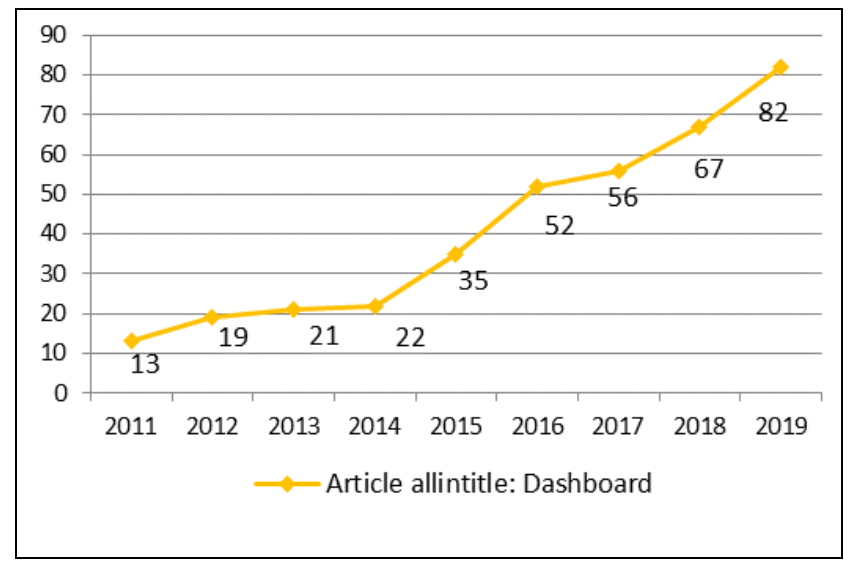

Figure 1. Dashboard" article numbers(scholar.google.com).

In the graph, it can be seen that the articles that used the term dashboard in its title and therefore the interest in the subject has been increased since the year 2000. In accordance with the business needs, dashboards are generally designed in three levels, namely; strategic, tactical and operational [6].

1 Strategic: Strategic dashboards collect basic institutional health indicators. It is a level that supports top managers to achieve opportunities for organizational expansion,

2 Tactical-Analytical: Designed to provide detailed data analysis of the data trends (what, why, how) Analytical indicator solutions are a level that attributes special importance to measure data variables on time (week, month, year, etc.),

3 Operational: In case of general situation of the business is being monitored, operational dashboards focus on key performance indicators (KPIs). This type includes information regarding the pre and postproduction processes on a workshop level. KPIs vary depending on industry and the metrics that are required by the personnel (sales, marketing, finance, etc.) This is a level at which the business activities are monitored in real-time.

An efficient and effective dashboard is a visual expression of the most significant information required to achieve a number of goals in the decision-making process.

\subsection{Related work}

The application of the dashboard overrides the existing data reports if it is conducted correctly and in accordance with a goal. At the same time, using the data analysis services with the base on data mining, the production process can be improved with the data-driven status. Especially, by dynamically creating action proposals based on the recommendations, proactive optimization shall be possible [6]. This enables a company to consolidate and visualize in enchantment its most valuable data in a regular manner for a specific purpose. This necessity makes the solution on the available system architecture difficult and accordingly the workers on this area are looking for new solutions in this field. The overall objective is to take advantage of the great amount of data in order to improve the performance and agility of the production operations on the existing system significantly [6].

It is revealed that general firm approaches can develop successful coping strategies with data mining methods. [7]. It is usually known that data mining methods are using when estimating trends and visualizing data correlations [8]. In particular, a special system is needed to support knowledge acquisition, learning and development [9]. It is stated that the needs in production systems can only be met by the analysis of accumulated data [10]. Analysis of operational data with data mining techniques is increasing and supported every day [11]. In general, standard data mining methodologies are estimation methods based on logistical regression, neural networks, decision trees, clustering and classification. For example, a national oil company has started the clustering method for integration of the management clustering in line with the objectives of the managers [12]. Attempts of manufacturers to use data analysis techniques for work performance can be seen as a key element [13]. For example, by using k-means, one of the clustering analysis techniques, the distribution of the assigned personnel can be provided on in the field of logistic management [14]. Therefore, by using a large number of data sets on different areas various applications have been realized with the clustering algorithms from data analysis techniques [15]. As can be seen in the practice, with the values that are created by the data and increasing the supply chain planning and performance capabilities the result values are also being increased [16]. Following the realization of the potential of the data mining and relevant technologies and innovations in the future, cross-feeding of the ideas shall be beneficial without any restriction of any classification option [17]. In data mining, data without any limits are used for a specified purpose for identification, prediction and explanation with the methods such as clustering, classification, association, etc. In addition to statistics, the development of the methods for information extraction led experts who are working in a decision makingprocess for the development of new algorithms and the change of the database systems for new searches. At this point, data mining is an important option in the interdisciplinary field for 
the solutions. In this sense, the decision-makers want to quickly analyze and increase the consistency of the estimation for the performance indicators during the process of purchasing. In our data, the k-means algorithm was determinative in its selection because of its fast classification of data, ease of processing and pre-determinability of the $\mathrm{k}$ class number. The k-means++ advanced model of the algorithm was used in the study. The requirement of the new technological approaches along with the available and existing systems has led to work in a different physical environment [18]. In addition, the collection, maintenance and analysis of accumulated data brings out the important technical challenges [19]. Today, ETL (Extract, Transform, Load) continues to be used in many sectors, in new technological approaches and in meeting the needs. Meanwhile, ETL has a crucial role in business intelligence projects that undertake technical service and decision-making support [20]. Today, ETL is considered as a good solution for collection and conversation of data from various data sources and for an analytical database to be designed [21]. ETL can meet all the analyses needed through the analytical database. Ultimately, data transformed into information with the help of indicators can be shared without increasing data and workload traffic on existing systems. The usage of mobile technologies for sharing is an important tool for the production systems of the future for facilitating flexibility and efficiency [3]. Therefore, every personnel from tactical and operational level must keep an eye on the process status and performance in real-time to be able to quickly respond to problems and find immediate solutions [22]. Many businesses are trying to reduce the number of suppliers in their lists because the selection between the suppliers is a difficult and long process. This situation weakens the businesses ' $n$ terms of competition and decision making. Our work is to prevent these weaknesses and enable decision-makers to make fast and accurate decisions with the approach of the dashboard and mobile application. Today, problem-based solutions are realized, mostly with the help of package programs. This need was demonstrated by eckerson'2011 in the use of dashboards with data analysis infrastructure.

In this context, the comparative table of the articles and applications are given below. The uses and levels of methods and techniques are shown in Table 1.

Table 1 shows that the business intelligence solution methodology and uses are quite interesting. In articles and applications, the working ground is mostly operational ground. Nine studies belong to automation processes at the operational level. At the tactical level, two studies are based on problems, while only one study is directed towards automation. At the tactical level, no work has been carried out on the mobile application. The work towards the prominent logistics sector is structured as repeatable according to special requirements. This particular work is similar as it is a sustainable work, but the absence of mobile sharing is an important difference.

The striking common point of the studied instrument panel model is business intelligence studies. Many of the research today is aimed at analyzing accumulated data and solving problems. We see these studies in the framework of business intelligence mostly in package programs that perform data analysis. While package programs provide fast solutions to problems, they are far from costly and sustainable for the enterprise. Making sustainable, real-time, fast and accurate decisions is extremely important for businesses. Qualified data experts can only meet these needs, which increase in importance with increasing competition. The need for data specialist and business intelligence models is seen as the most serious bottleneck in the near future [31]. The table shows that after business intelligence, performance and data analysis studies have increased. In addition, the combination of methods and techniques is another common feature of the studies. In this context, the instrument panel is an important integrator and presentation tool. The instrument panel model creates a suitable infrastructure for the business intelligence studies needed at the tactical and strategic level. The features of the instrument panel model shared in the table are an example of a new approach that supports the solution sought within the enterprise and emphasizes the combination of methods. Therefore, it is a new road map that will attract the attention of researchers.

Table 1. Similarity of the instrument panel model in resource.

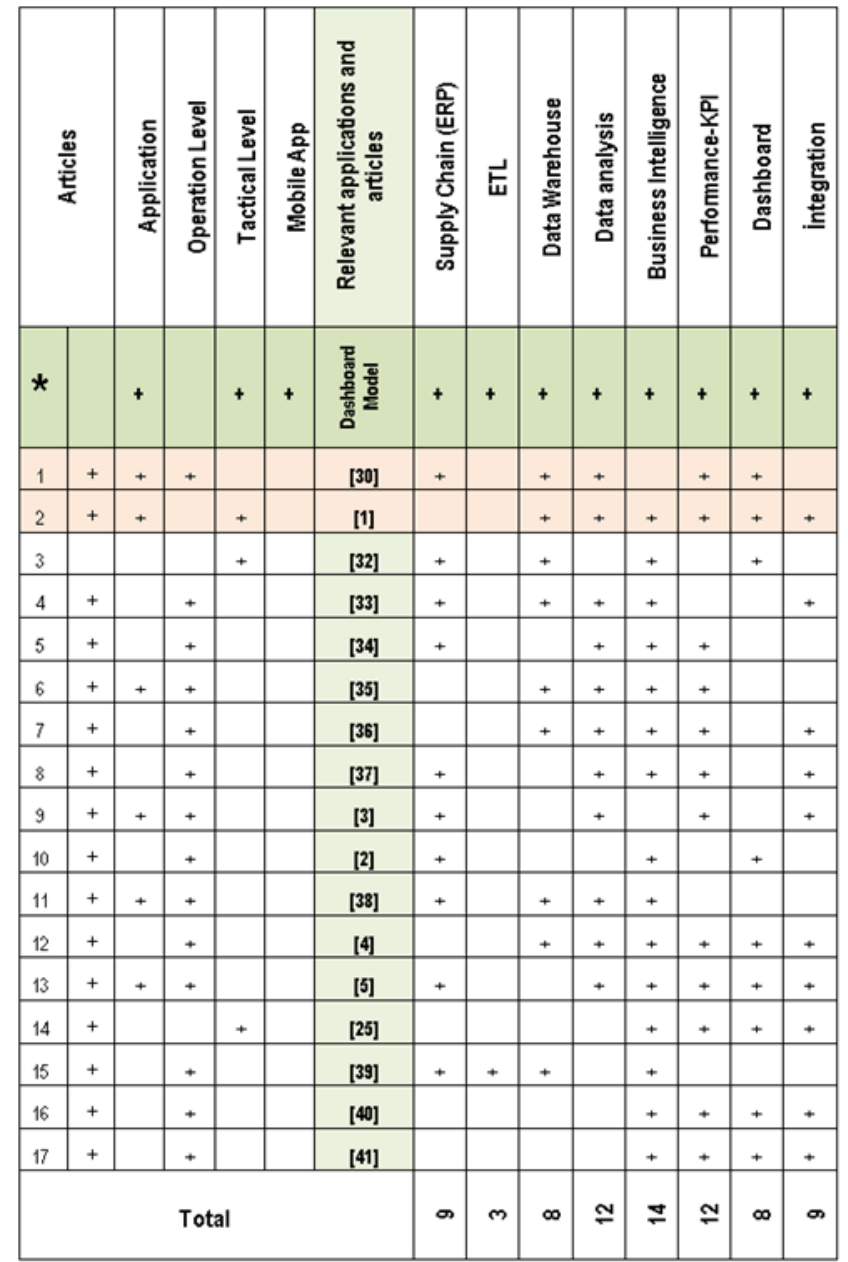

The aim is to make the combination of methods and techniques sustainable. In this context, an application model of Volvo's logistics area is the best example of this [30]. In the example, the unity of methods is predicted and iterative data sharing is performed. The difference from our study is remarkable in the analysis of accumulated data and mobile sharing. In another example of the automotive industry, an operational dashboard with data analysis infrastructure has been realized [12]. The sample is considered similar to the combination of methods, and different at the enterprise level. Works are carried out rapidly with mobile instruments, where the instrument panel is 
combined with refined data Figure 2. In a study by Ronal van loon, it showed the development of dashboard systems Table 2.

Table 2. Development of decision making systems (Ronald Van Loon, December 2019).

\begin{tabular}{cccc}
\hline $\begin{array}{c}\text { Level of systems used } \\
\text { in decision making }\end{array}$ & Time & Auto/Man & auto. \\
\hline Strategic & 1 mou.-1week & Manual & No \\
Tactical & 1week-1day & Manual & No \\
Operational & $<$ 1Minute & Auto & Yes \\
\hline
\end{tabular}

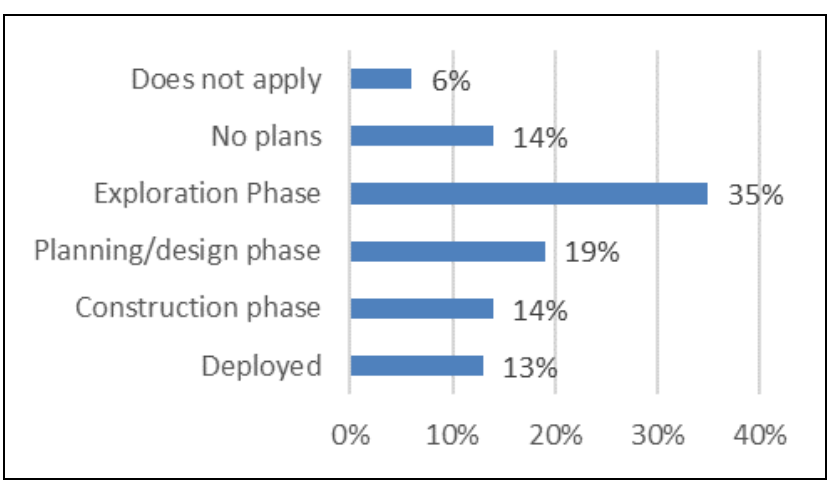

Figure 2. Dashboard usage rates.

Accordingly, the status of the instrument panels at the tactical level is under development. At this stage, rapid data analysis and systematic solution searches of the systems continue. The constantly updated instrument panels are seen as a new workspace. Today, this field will complete its development with the help of experimental studies and models.

In the first stage of this study, the accumulated data of a production system of a business were examined. In the second stage, the data were replicated with the accumulated data by using artificial immune system clonal selection algorithm and the data were classified by k-means from the data mining algorithms. In the third stage, the classified data are processed with the determined performance indicators and the weighted average method. Finally, the processed data were shared with the dashboard and mobile applications tools as the life curves of the suppliers. The article represents a new model by structuring the business requirements and available data. In Chapter 2, the architecture of the method on the application and the analysis that were realized were shared. The details of the application are provided in Chapter 3. In Chapter 4, results, evaluation and future studies were emphasized.

Most of the businesses want to use the large amount of data they have obtained in time for various reasons in an economic and scalable manner. Disk-based systems are inadequate to provide the desired performance on the accumulated data, especially given the increase in data volume. In some cases, the duration of the responses of the report requests exceeds the acceptable periods of time. In some cases, where the depth and complexity of the report is so increased that the report requests cannot be even responded. These report requests, which work on accumulated data and occupy the system for a long time, increase the data traffic in the system and decrease the performance of operational transactions (stock movement operations, workshop work orders, etc.) [23]. Therefore, providing target-oriented and real-time information at strategic, tactical and operational levels for manufacturing businesses is an essential success factor. It can be seen that improving processes, data analysis and evaluation are the easiest options to achieve this success factor.

\subsection{Preparation of the data}

The dashboard, with its increased usage of each day, has started to play a very essential role in providing fast and accurate information for the businesses. Our study is developed by limiting the work in purchasing department. In the study conducted on the data provided by the purchasing department, the evaluation scale was defined as good, medium and weak and the suppliers were identified with the letters A, B and C. The identification both facilitated the process of evaluation and contributed to the speed of the data processing. Key Performance Indicators (KPI) that will contribute to the evaluation of the supplier were determined as "quality", "price", "delivery" and "satisfaction" by contacting managers individually. Performance indicators were identified by the importance attributed to materials of the suppliers and the supplier points were obtained by the weighted average method. The obtained points were shared with the managers with the mobile environments in the form of indicators by transferring to graphical form regarding the classified suppliers. In order to improve today's modern processes, the architectural plan of our study which can be a solution to the companies looking for improvement can be seen in Figure 3.

\begin{tabular}{|c|c|c|c|c|}
\hline \multirow{4}{*}{ 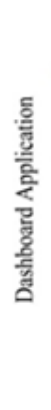 } & $\begin{array}{l}\frac{6}{5} \\
\frac{8}{5} \\
5\end{array}$ & 6. Sharing & $\begin{array}{c}\text { Software } \\
\text { Level }\end{array}$ & 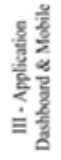 \\
\hline & \multirow{3}{*}{ 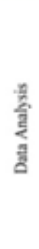 } & 4. Weighted Average & $\begin{array}{l}\text { Statistics } \\
\text { Analysis } \\
\text { Level }\end{array}$ & \multirow{3}{*}{ 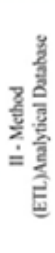 } \\
\hline & & 3. K-Means Algorithm & $\begin{array}{c}\text { Data } \\
\text { Mining } \\
\text { Level }\end{array}$ & \\
\hline & & $\begin{array}{l}\text { 2. Artificial Immune System Clonal } \\
\text { Selection Algorithm }\end{array}$ & $\begin{array}{c}\text { Data } \\
\text { Replication } \\
\text { Level }\end{array}$ & \\
\hline \multicolumn{5}{|c|}{ 1. Manufacturing System (ERP) } \\
\hline
\end{tabular}

Figure 3. Dashboard architecture.

In the first step of the architectural plan, the data for the dashboard shall be determined by the evaluation of the available system. In the first step of the architectural plan, an existing system review was made. The data to be used in the algorithm were randomly determined as 30\% test and $70 \%$ education without being changed. In the second step, if the data that have been prepared for the analysis is not sufficient, then the data shall be replicated with the artificial immune system and the clonal selection algorithm. The main purpose of duplication is to duplicate the data in order to obtain sufficient quantity. In the study, a sufficient and limited number of initial datasets are created from randomly selected data that are cleaned and edited. The suitability value (shortest distance) is calculated with each feature (quality, price, delivery, satisfaction) Euclidean function. The properties with the lowest suitability value are selected. Then the data set is cloned regarding the suitability value. According to the condition of the data available, replication is applied by keeping the compliance values constant. The stop criterion is defined as the five repetitions of the test data set. In Table 3, the frequency distribution values of the discrete sample data set at hand are shared. 
Table 3. Sample data set frequency distribution table.

\begin{tabular}{|c|c|c|c|c|c|c|c|c|}
\hline 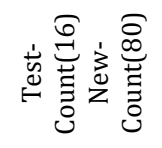 & 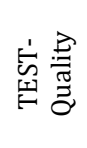 & 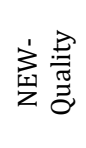 & 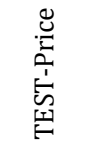 & 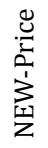 & 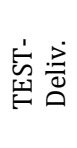 & 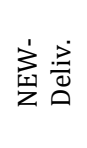 & 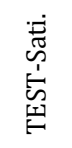 & 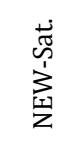 \\
\hline $\begin{array}{c}1 . \\
(0-33)\end{array}$ & 0 & 0 & 0 & 0 & 0 & 0 & 0 & 0 \\
\hline $\begin{array}{c}2 . \\
(34-66)\end{array}$ & 56.25 & 54.25 & 93.75 & 93 & 62.5 & 61.25 & 12.5 & 14.25 \\
\hline $\begin{array}{c}3 . \\
(67-100)\end{array}$ & 43.75 & 45.75 & 6.25 & 7 & 37.5 & 38.75 & 87.5 & 85.75 \\
\hline
\end{tabular}

If the deviations between the test data set and the new data set do not exceed $10 \%$, the operations are continued. Otherwise, the data set is reviewed. In the third step, the obtained data shall be classified and decomposed by the k-means algorithm. In the fourth step, the decomposed data shall be listed by the weighted average method. In the fifth step, the data in the time axis shall be converted into graphics and indicators. In the sixth step, the dashboard shall be shared with the personnel within the frame of the authorization.

During the obtainment of the performance indicators, the accumulated data on the available system is the determinant factor. Although there is some deficiency in the product quantity of the supplier for the data, the accuracy, renewal, process, and diversity met the requirements of the characteristics of the data. In this context, under the title of the quality; control of the quality standards of the supplied products, quantities of scraps, under the title of pricing the ability to supply the valuable products in a cheap manner, under the title of the delivery on time and the quality of the packaging and finally under the title of the satisfaction, the requirement to establish long-term strategic relations are the prominent details of the performance indicators. The supplier files on the existing ERP (Enterprise Resource Planning) system are separated and arranged as data files that are supporting the performance indicators. In the event that the data supporting the performance indicators are insufficient, new solutions must be created. The artificial immune system based on the clonal selection algorithm is mostly used when the acquired data is insufficient and also to reproduce the data by working on such data.

Artificial immune system and clonal selection algorithm: Artificial immune system is an algorithm inspired by the natural immune system of humans. This algorithm is based on the principle of recognizing and eliminating foreign substances called antigens by producing antibodies against them. In terms of complexity, the immune system is as complex as the human brain. The essential features of the immune system are very suitable for solving problems in engineering, computer sciences and many other fields.

The basic parameters of the algorithm that is forming the system;

Detection of the Anomaly: The immune system can identify and react to external substances (pathogens) that the body has never encountered before.

Distributed Detection: All cells in the system are distributed throughout the body and they are not centralized. Any response to the antigens that are occurred in the system are in a matter that is distributed throughout the body.

Noise Tolerance: There is no need to fully recognize the pathogens coming from outside.

Uniqueness: Each individual has their own immune system.

Reinforced Learning: The system can learn pathogens and the system can also show its response more quickly when faced with similar pathogens.

Change: The system tries to produce the best antibody, for this reason, the system produces different antibodies for various antigens.

Memory: It has a dynamic memory. Similar antigens are responded by the same types of antibodies. Therefore, the noises to occur can be tolerated.

The Clonal Selection Algorithm is inspired by the reproduction of the response against the antigens in the entire system in an essential act as for the artificial immune system. Antibodies increase at the rate as their detection; hence, the detected ones are selected instead of the non-detected ones. This algorithm provides a multiplication of the data set by creating artificial data in the data sets that have a small number of elements. This artificial new data set that is created at the same time can be used for the training for another artificial intelligence system. In the algorithm, a test and training data set will be created for the data reproduction process. New individuals will be produced from the individuals in the test data set and new individuals shall be added to the total data set. In a single iteration, the algorithm generates data by the number of the test data set. By running the algorithm many times, the data set can be expanded in a desired fashion. The flow diagram of the algorithm is provided in Figure 4.

The lack of data on existing and available systems, the fact that the data was noisy and the reproduction of the data without any deficiencies on the basic features was the decisive factor in the choice of the clonal selection algorithm of the artificial immune system. Each new data that is replicated over a master data is an exact copy of the master data. Mutation is used to provide diversity on data [24]. Artificial immune system-based algorithms essentially are divided into two sections: classification-based and network-based. The algorithm with distinctive attributes works simultaneously on the class in the search field [25]. Instead of the deterministic ones, the algorithm uses the rules of transition based on probability and it does not use differentials or any other information [26]. As a new optimization algorithm, the clonal selection algorithm has been successfully applied to various engineering problems 
[27]. The clonal selection algorithm has been shown to contribute to the success of the classification, along with the training of the protein-specific data, by duplicating and reproducing [28]. Euclidean distance was used as a criterion of suitability in clonal selection. Verbal data was not used for any classification process in coding. The result was made over numerical data. The selected training datasets have been cloned with the smallest distance criterion. In our study, we have focused on the adequacy of supplier data in terms of quantity, trained and duplicated with the clonal selection algorithm.

\begin{tabular}{|c|c|}
\hline \multicolumn{2}{|l|}{ Start } \\
\hline \multicolumn{2}{|c|}{$\begin{array}{l}\text { Data set,divided by two. } \\
\text { ( Testing and Training ) }\end{array}$} \\
\hline \multicolumn{2}{|c|}{$\begin{array}{l}\text { Find the nearest training data in the test data set. } \\
\qquad(\mathrm{C} \text { data set ) }\end{array}$} \\
\hline \multicolumn{2}{|c|}{$\begin{array}{l}\text { The } \mathrm{C} \text { data set is duplicated. } \\
\qquad\left(\mathrm{C}^{*} \text { data set ) }\right.\end{array}$} \\
\hline \multicolumn{2}{|c|}{ Mutate the $\mathrm{C}^{*}$ data set } \\
\hline \multicolumn{2}{|c|}{$\begin{array}{l}\text { Find the closest } C^{*} \text { data to the test data set. } \\
\text { ( new data sets ) }\end{array}$} \\
\hline End & \\
\hline
\end{tabular}

Figure 4. Flow diagram of clonal selection algorithm of artificial immune system.

\subsection{Classification of the supplier}

Workable supplier data is classified by k-means from data mining clustering algorithms. In this study, the data that is based on the indicators are transferred from the ERP system database to the ETL database with a specified file format and relationship. The main purpose of transferring to different physical environments is to update the indicators in real-time without increasing the processing load on the operational data. The analytical database, which is updated as often as desired, creates a suitable basis for different information inferences and complex analyzes. On the Dashboard, the performance indicator identification process is performed once on the application. Once completed, the built-in dashboard with the existing ERP system becomes technically interconnected. Therefore, within the required indicators, segment-specific encodings need to be configured once and defined to the dashboard.

The ability to correct mathematical models to be met by the kmeans algorithm in the cluster of performance indicators was the most important criterion. The other criterion in the selection is that the k-means algorithm, the criteria on the indicators, can determine the levels. This decisive situation can be used as an effective parameter on the final product quality.
K-means clustering: K-means clustering is a classification method that is used for solving the clustering problem with an essential idea of dividing a data cluster consisting of $n$ units of data objects $(X)$ to $\mathrm{k}(k \leq n)$ units of cluster as provided to an input parameter [29].

This method is one of the most preferred methods for classifying data into homogeneous subgroups and classifying them according to similarities and has a non-hierarchical structure. With this algorithm, relatively homogeneous groups are formed which are related to each other according to the determined criteria. Hundreds of data without class information is converted to set $\mathrm{k}$ units of sets. This operation is to minimize the sum of the squares of the points assigned to the clusters from the center of the cluster (1).

\section{the euclidean distance :}

$$
D_{i j}=\left(\sum_{k=1}^{n}\left(x_{k i}-y_{k j}\right)^{2}\right)^{1 / 2},
$$

$$
\begin{gathered}
D_{i j}=\text { distance between cases } i \text { and } j, \\
X_{k i}=\text { value of variable } X_{k} \text { for case } j
\end{gathered}
$$

Each cluster is represented by its own center. Therefore, when data with similar criteria are assigned to the same cluster, the data with minimum similarity are assigned to different clusters. Finding the appropriate number of k cluster numbers by trial is the weak point of the method. The steps of the K-means algorithm are provided in Figure 5.

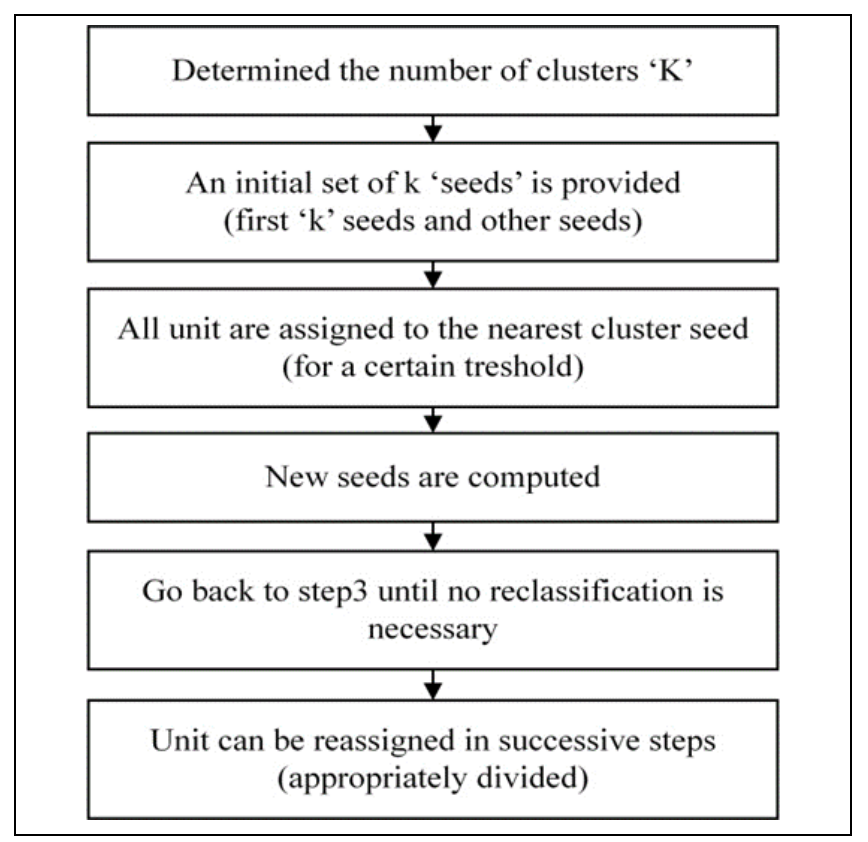

Figure 5. Steps of K-means algorithm.

In this study, the number of clusters of the suppliers is determined as $\mathrm{k}=3$ in accordance with the values of the performance indicators and the needs of the decision-makers. The resulting algorithm results were visualized and all the results obtained were shared with the decision-makers.

Life Curve of the Supplier: Many analytical hierarchy processes (AHP), fuzzy logic (Fuzzy Logic) methods are used on supplier problems. In this study, instead of applications based on AHP 
and fuzzy methods performed with a limited number of data the method is modeled overall non-limited data on the existing production system. In our study, based on the supplier data and the requirements of the decision-makers, an evaluation model was developed. The preparation and classification of supplier data on the existing system have been expressed as an initial operation prior to evaluation. Provided that each business can identify performance indicators differently, the weighted average may be considered as a good formula. Therefore, for the supplier life curve, each performance indicator weight can be determined in a flexible manner. For each supplier, the weighted average values that are obtained emphasize the importance of that supplier for the business. This importance is the average of the weight value and the material score in the acceptance of the importance of each material coming from the supplier. The calculation is provided in Table 4. Each weighted average value that is obtained is stored in the table. At the final stage, the weighted averages are visualized in the time axis and defined as the life curve of the supplier.

Table 4. Weighted average calculation chart.

\begin{tabular}{cccc}
\hline Performance Indicators (KPI) & $\begin{array}{c}\text { wEight } \\
\%\end{array}$ & $\begin{array}{c}\text { scoRe } \\
1-10\end{array}$ \\
\hline 1 & Quality & 35 & 9 \\
2 & Price & 30 & 6 \\
3 & Delivery & 20 & 8 \\
4 & Satisfaction & 15 & 5 \\
\hline \multicolumn{2}{c}{ Total } & & 732 \\
\multicolumn{2}{c}{ Weighted Average } & 183 \\
\hline
\end{tabular}

In the formula $E_{1}$ shall represent the weight of the first value and $E_{2}$ shall represent the weight of the first value, $E_{n}$ represents the value of the unit of $n$. The values to be averaged are shown as $R_{1}, R_{2}, \ldots R_{n}$. The ratio of the weight of each value with the weight of each value is the ratio of the sum of all the weight factors (2).

In application, the weighted average score is calculated by calculating the 4 units of performance indicators of the supplier. Table 4 states an example table for weighted average score. The final points received are instantly posted on the mobile application. This visualized information can be shared with the dashboard application for all levels of personnel within their limits of authorization.

In our study, the final version of the records regarding the periods in which the suppliers will be evaluated is provided in Figure 6. In the analytical database, a good basis has been created for compiling supplier records on a file and applying the k-means algorithm. Transactions were carried out on 251 registered suppliers as the content is included in the table. The $\mathrm{k}$-means algorithm was applied to the selected performance quality criterion and the material titled ID $=\mathrm{H} 03003020007$.

\begin{tabular}{|c|c|c|c|c|c|c|c|}
\hline \multicolumn{6}{|c|}{ Supplier Evaluation Filie [GPUC01 h03_062018] } & \multicolumn{2}{|r|}{$0 x$} \\
\hline Trans.No & 7 Company Code & Y Slock Code & Y Current Code Y Y & Qually $\%$ & Price $Y$ & Delivery $\mathrm{F}$ & Satisfaction \\
\hline 1 & Zivella & H03003020007 & Sc03002001 & 95 & 55 & 80 & 90 \\
\hline 2 & Zivella & H03003020007 & Sc03002001 & 80 & 57 & 95 & 85 \\
\hline 3 & Zivella & H03003020007 & Sc03002001 & 80 & 58 & 95 & 85 \\
\hline 4 & Zlvella & H03003020007 & Sc03002001 & 85 & 58 & 90 & 90 \\
\hline 5 & Zivella & H03003020007 & Sc03002001 & 85 & 58 & 90 & 80 \\
\hline 4 & Zivella & H03003020007 & Sc03002001 & 80 & 57 & 85 & 85 \\
\hline 4 & Zivella & H03003020007 & Sc03002001 & 85 & 57 & 85 & 90 \\
\hline 4 & Zivella & H03003020007 & Sc03002001 & 90 & 58 & 90 & 85 \\
\hline 4 & Zivella & H03003020007 & Sc03002001 & 85 & 57 & 95 & 85 \\
\hline
\end{tabular}

Figure 6. Supplier score table.
The algorithm worked for approximately 116 seconds on 2541 transaction data from registered suppliers. As a result, the number of suppliers divided into classes A, B and C emerged as 91,131 and 29, respectively. The drawn life curve is realized through the performance indicator scores of all products delivered. This is the indicator of the supplier's current status in real-time.

\section{Application}

The study area is a medium-sized furniture manufacturer that uses an ERP system. The resulting model requires a preliminary examination to be implemented in similar enterprises and for the integration of the existing production system. The resulting dashboard model application is integrated with the existing system. In the application, the existing ERP system was protected, and the integration of the dashboard with the intermediate codes was completed. Thus, the data of the defined performance indicators are automatically updated in the determined periods unless the requirements are changed. ETL is designed to provide services to users as a service computer via the analytical database (Figure 7). Access to the application via the internet and intranet can be provided through notebooks and tablets.

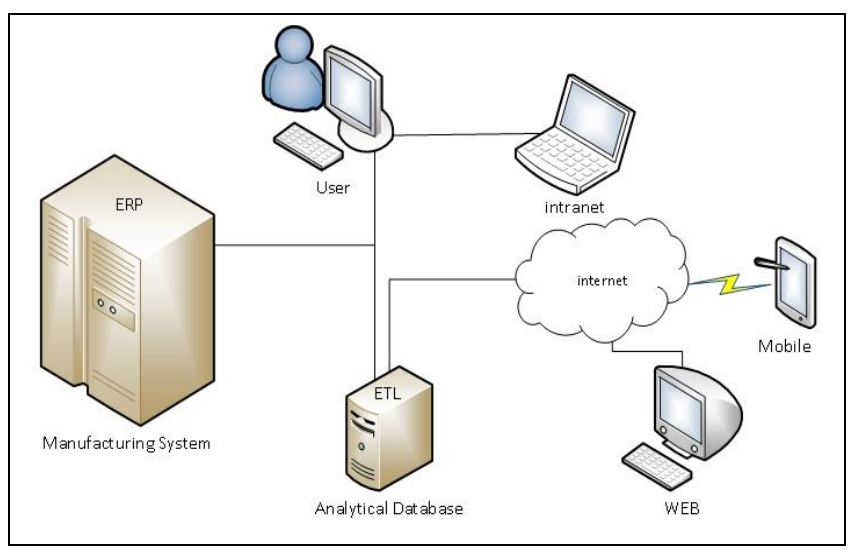

Figure 7. System architecture.

Indicator Access traffic is facilitated by the architectural design and at the same time with the sharing of visual objects based on communication, additional gains in terms of speed and security have been achieved. Dashboard emphasizes the importance of comprehensive data management and data analysis, as well as the user-centered and case-sensitive presentation of the obtained information.

In Figure 8, ETL is defined as a new component that demonstrates the relationship of the analytical database with the ERP system on the supplier data. The Dashboard can be used at the tactical level for supplier relationship management, or the strategic level and if desired can also be used by the top management.

The K-means algorithm is based on the supplier quality performance evaluation for the material with the code of ID = H03003020007. Suppliers are divided into classes A, B and C through the resulting clusters. Decision-makers can easily perform supplier evaluation through these classes at the point of the quality.

In Figure 9, it can be seen that from the data that have been obtained from the performance indicator classes, more detailed results can be obtained regarding the evaluation of the suppliers. 


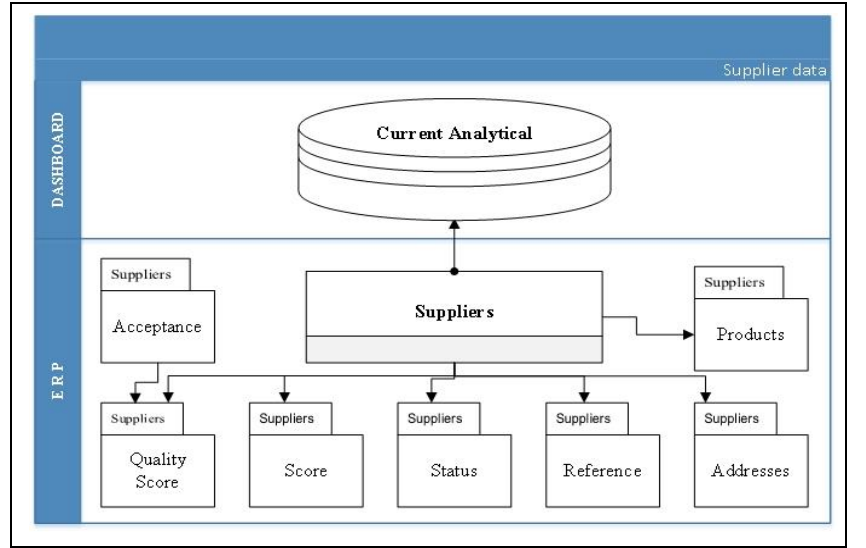

Figure 8. Supplier data, entity relationship diagram.

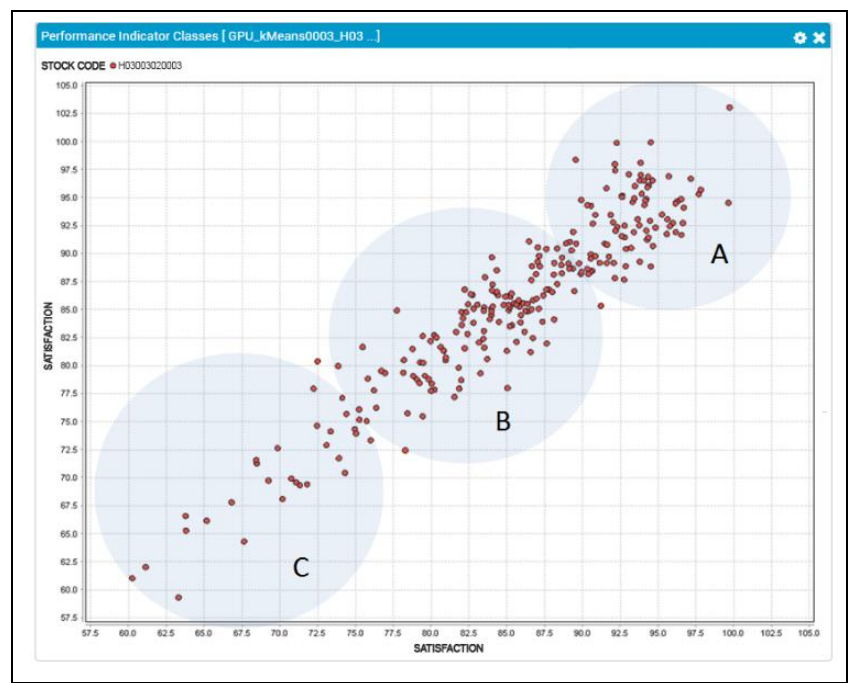

Figure 9. Satisfaction performance indicator classes.

This indicator, created for "Satisfaction" performance classes, takes place on the dashboard, in real-time, in the following sections: quality, price, and delivery. Suppliers are evaluated in their class for the life curve indicator. Suppliers are evaluated in their class for the life curve indicator. The Dashboard application will be repeated according to the frequency of supplier replacement. All statistics on performance indicators are business-specific assessments carried out on quality, price, delivery, and satisfaction of the suppliers that are realized on indicator data. Supplier evaluation has gained the ability to monitor and control, along with updates in daily periods. The aim is to realize in real-time. If the acquired achievements can be evaluated by the decision-makers in a fast and correct manner that the response to the changing conditions can be as fast. The calculated weighted average scores are designed and defined graphical form. This design and identification were tried to be determined in accordance with the training and cognitive adaptation of the personnel. In Figure 10 it is shared that the life curve of the first 9 suppliers in Group A over 7 months, based on the weighted scores.

The supplier life curve is the indicator of strategically determined suppliers based on performance-based criteria. The indicator shows the lifeline of the 4 essential performance criteria on the basis of the supplier over a 12-month period of time. The 7-month data of the suppliers were analyzed and the supplier relationship was shown in the obtained indicator. Supplier named Supp_09 started in the $4^{\text {th }}$ month. With the same evaluation rules, it is seen that the material purchases made from the supplier with the number Supp_05 were terminated in the 4th month. Although there were fluctuations after the first accepted performance values of other suppliers, they remained to suppliers. It can be seen that with the month 4 deliveries of the Supp_03 supplier, some notifications have been submitted and following that the relationship was returned to the expected level.

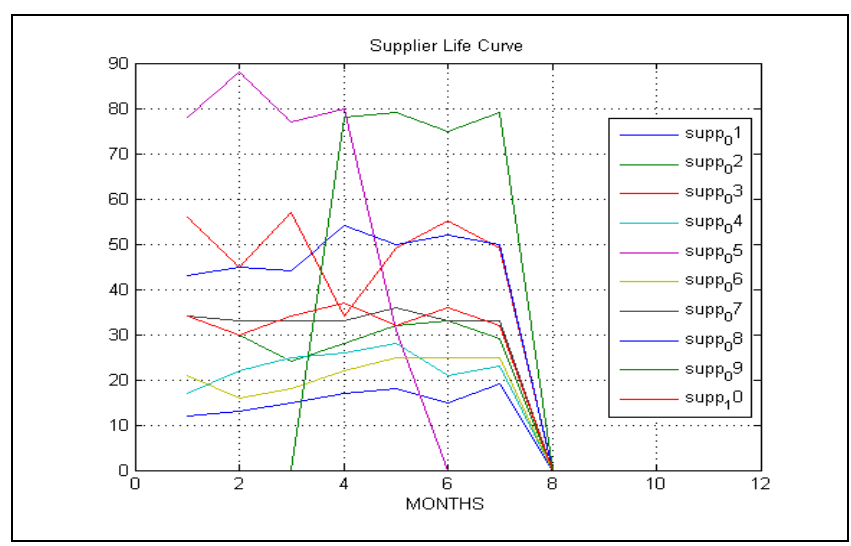

Figure 10. Class A, supplier life curve.

Indications shall be crated with the desired sensitivity in accordance with the algorithm results on the dashboard application. When requested, indicators and background data are exported and reported in different formats. With the acquired indicators, the change of supplier relations overtime shall be monitored and controlled. In addition, indicators facilities the purchase manager to take quick and correct decisions regarding the supplier. The best visible option for the real-time situation of the supplier by the acquired life curve shall make the business stronger in the markets that require low cost and high quality and increasing competitive levels.

For the supplier life curve, a road map was determined through the ERP system, and the preparation and analysis stages of the data were systematized. The supplier evaluation system that is created is a decision support tool to ensure the reliability of the products and services that extend to the customer. Settings and user interfaces are created in order to increase the usability of the Dashboard and to make the process systematic. (Figure 11) On the program interface, along with the display features of the data, many options such as search and query are defined on the screen.

The personnel can access the indicators from both the web environment and mobile platforms within the scope of the defined account and authorization limits. Each message based on communication and information can be managed from this screen, if necessary, for each level of personnel. In the case of more than one and dispersed businesses in supply chain management, the indicators of each business unit can be monitored and shared. Each defined dashboard page is stored and reused if necessary. The indicators are categorically classified and authorized for each section.

\subsection{Mobile dashboard}

The Dashboard mobile application has been developed to work on all operating systems (Figure 12). 


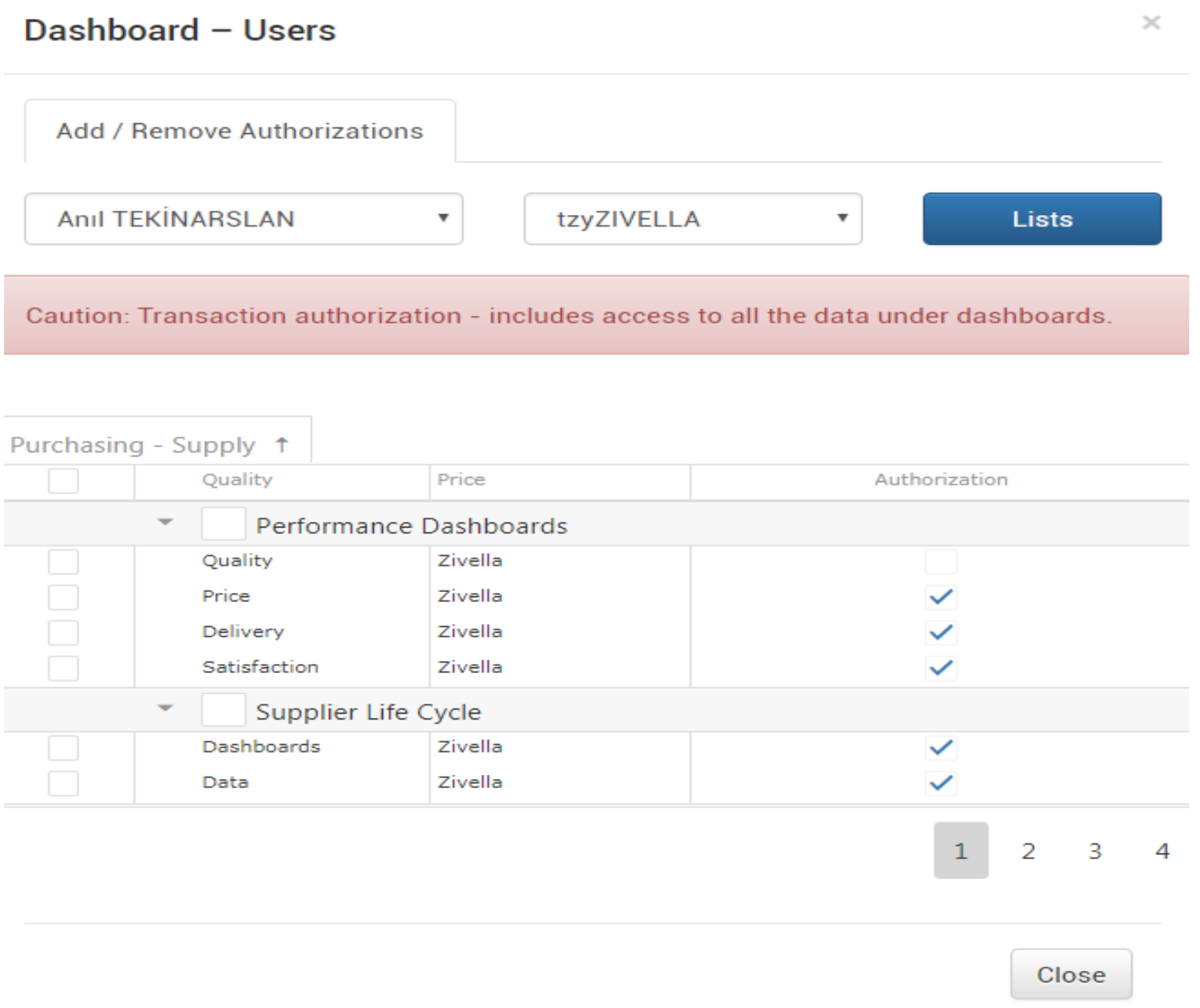

Figure 11. Dashboard settings.

\begin{tabular}{ccc}
\hline$\Lambda$ & Harmony DashBoard & ร $41 \%$ 10:09 \\
$\equiv$ & H
\end{tabular}

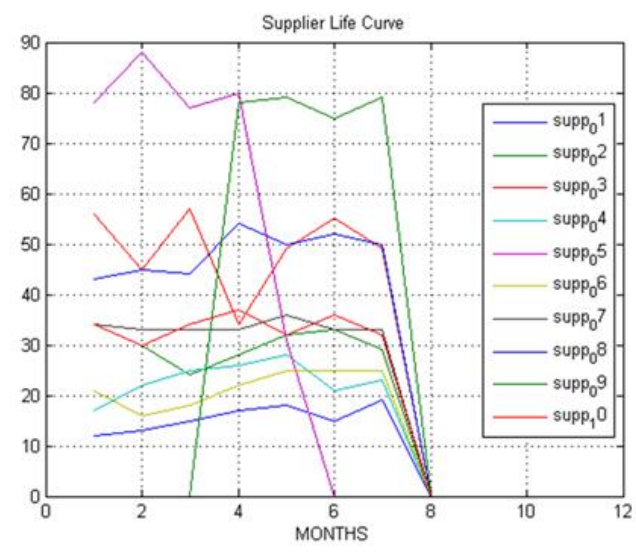

Figure 12. Mobile dashboard.

The implemented mobile application is based on a client-server architecture and includes a server-side analytical data processing, update, and visualization layer. The client, in other words, the user access layer, is used as a web browser. The mobile dashboard simplifies the sharing of information needed at any level of the business, such as the current status, duration, and quality of the entire process. The mobile dashboard simplifies the sharing of information needed at any level of the business, such as the current status, duration, and quality of the entire process. In addition, the dashboard provides information on work instructions and improvement suggestions, such as process information and process communication. In today's production systems, mobile devices have a very important place in terms of providing information, flexibility, and efficiency. Especially, it is one of the most useful tools for the strategic and tactical level of personnel to react quickly and produce solutions. Therefore, personnel want to monitor the process status and performance in real-time.

The mobile application has been developed considering both follow-up and communication processes. Indicators are with user-friendly design which can be authorized and managed for all personnel when needed.

\section{Conclusion and evaluation}

The dashboard model that has been subject to works shall require feedback and monitoring because the dashboard is affected by the application area activities and the changing needs. The developed system can be managed through a supply chain management application in medium-sized enterprises. 
Therefore, different scale enterprises and industries require additional analyses in order to provide the same levels of contribution. During the implementation of the application, no adverse effect of the dashboard application on the operational data load of the current system was observed.

A new model is presented by using real-time and data analysis methods in the article. It has been shared in production systems to provide a different perspective for analytical data-based solutions. The dashboard is designed to improve the existing information management system, in particular the purchasing department of the manufacturing business. As a result of our interviews with the personnel on the implementation model, it was observed that, unlike the previous system, the personnel increased their ability to make accurate and quick decisions. The study essentially increased the reliability and speed of the decisions taken during the production stages with the dashboard tool. In addition to the available system, the dashboard is an important support tool for decision=making while increasing communication at all levels. in particular, the supplier life curve as provided in Figure 10 improved the decision-making process at all levels and facilitated control of relations with suppliers. In the future, the model can be developed using different data analysis techniques and performance evaluations can be conducted. The proposed model can be adapted to data analysis and other sections (production, quality control, etc.) In addition, by focusing on the visualization techniques, designs can be developed in accordance with the cognitive adaptation of the decisionmakers.

\section{Acknowledgment}

We would like to thank the "Kurumsal Yazılım ve Danıșmanlık" company team for their support during the research and implementation phases.

\section{Author contribution statements}

In the scope of this study, Yüksel Yurtay contributed to the formation of the idea and the design, literature review, the assessment of the obtained data, supplying the material used, examining the results; Murat Ayanoğlu contributed to spelling and checking the article in terms of content amd examining the results.

\section{Ethics committee approval and conflict of interest statement}

There is no need to obtain permission from the ethics committee for the article prepared.

There is no conflict of interest with any person / institution in the article prepared.

\section{References}

[1] Chopra S, Meindl P. Supply Chain Management: Strategy, Planning \& Operations. 6 $6^{\text {nd }}$ ed. New Jersey, USA, 2007.

[2] Pattnaik S, Sutar MK, Govindan K. "Supply Chain integration in relation to manufacturing industries". IEEE International Conference on Computers \& Industrial Engineering, Troyes, France, 6-9 July 2009.

[3] Yigitbasioglu OM, Velcu O. "A review of dashboards in performance management: Implications for design and research". International Journal of Accounting Information Systems, 13(1), 41-59, 2011.
[4] Lempinen H. "Constructing a design framework for performance dashboards". Nordic Contributions in IS Research, 1(1),109-130, 2012.

[5] James T. "Smart factories". Engineering \& Technology, 7(6), 64-67, 2012.

[6] Gröger C, Stach C, Mitschang B, Westkämper E. "A mobile dashboard for analytics-based information provisioning on the shop floor". International Journal of Computer Integrated Manufacturing, 29(12), 1335-1354, 2016.

[7] Collins JD, Worthington WJ, Reyes PM, Romero M. "Knowledge management, supply chain technologies, and firm performance". Management Research Review, 33(10), 947-960, 2010.

[8] Peral J, Mate A, Macro M. "Application of data mining techniques to identify relevant key performance indicators". Computer Standards \& Interfaces, 54(2), 76-85, 2017.

[9] Choudhary AK, Harding JA, Lin HK, Tiwari MK, Shankar R. "Knowledge discovery and data mining integrated (KOATING) Moderators for collaborative projects". International Journal of Production Research, 49(23), 7029-7057, 2011.

[10] Banerjee A, Bandyopadhyay T, Acharya P. "Data analytics: Hyped up aspirations or true potential?". The Journal for Decision Makers, 38(4), 1-11, 2013.

[11] Lau HCW, Ho GTS, Zhao Y, Chung NSH. "Development of a process mining system for supporting knowledge discovery in a supply chain network". International Journal of Production Economics, 122(1), 176-187, 2009.

[12] Hadighi SA, Sahebjamnia N, Mahdavi I, Akbarpour SM. "A framework for strategy formulation based on clustering approach: A case study in a corporate organization". Knowledge-Based Systems, 49(1), 37-49, 2013.

[13] Olson DL, Shi Y. Introduction to Business Data Mining. $1^{\text {nd }}$ ed. London England, USA, McGraw Hill, 2006.

[14] Faliu YF, Moon I. "Extended K-Means algorithm". $5^{\text {th }}$ International Conference on Intelligent Human-Machine Systems and Cybernetics, Hangzhou, China, 26-27 August 2013.

[15] Fahad A, Alshatri N, Tari Z, Alamri A, Khalil İ, Zomaya AY. "A survey of clustering algorithms for big data: taxonomy and empirical analysis". IEEE Transactions on Emerging Topics in Computing, 2(3), 267-279, 2014.

[16] Chae B, Olson D, Sheu C. "The impact of supply chain analytics on operational performance: A resource- based view". International Journal of Production Research, 52(16), 4695-4710, 2014.

[17] Olson DL. "A Review of supply chain data mining publications". Journal of Supply Chain Management Science, 1, 1-2, 2020.

[18] Chaudhuri S, Dayal U, Ganti V. "Database technology for decision support systems". IEEE Transactions on Automation Science and Engineering, 34(12), 48-55, 2001.

[19] Ren C, Liu Y, Guo Y. "Fuzzy evaluation on supply chain competitiveness based on membership degree transformation new algorithm". Journal of Chemical and Pharmaceutical Research, 6(2), 139-144, 2014.

[20] Jun T, Kai C, Yu F, Gang T. "The research \& application of ETL tool in business intelligence project". International Forum on Information Technology and Applications, Chengdu, China, 1-8 May 2009.

[21] Liu L. "Supply Chain Integration through Business Intelligence". International Conference on Management and Service Science, Wuhan, China, 09-11 August 2010. 
[22] Tokolaa H, Grögerb C, Järvenpääc E, Niemi E. “Designing manufacturing dashboards on the basis of a Key Performance Indicator survey". 49th CIRP Conference on Manufacturing Systems, Budapest, Hungary, 25-27 May 2011.

[23] Akpınar MY, Gayberi M, Orman E, Ögütücü ŞG. "Kurumsal raporlama çözümlerinde bellek içi veritabanı kullanımı". Turkish National Software Engineering Symposium, Güzelyurt, KKTC, 8-10 September 2014.

[24] White JA, Garrett SM. "Improved pattern recognition with artificial clonal selection?". Artificial Immune Systems, 2787(1),181-193, 2003.

[25] Zheng J, Chen Y, Zhang W. "A Survey of artificial immune applications". Artificial Intelligence Review, 34(1), 19-34, 2010.

[26] Hatata AY, Osman MG, Aladl MM. "A review of the clonal selection algorithm as an optimization method". Leonardo Journal of Sciences, 30(1), 1-14, 2017.

[27] Babayigit B, Guney K, Akdagli A. "A clonal selection algorithm for array pattern nulling by controlling the positions of selected elements". Progress In Electromagnetics Research B, 6(1), 257-266, 2008.

[28] Yavuz BÇ, Yurtay N, Ozkan O. "Prediction of protein secondary structure with clonal selection algorithm and multilayer perceptron". IEEE Access, 6(1), 45256-45261, 2018.

[29] Vincent OR, Makinde AS, Salako OS, Oluwafemi OD. "A selfadaptive k-means classifier for business incentive in a fashion design environment". Applied computing and informatics, 14(1), 88-97, 2018.

[30] Gustafsson J, Karlsson E. Supplier Performance Dashboard At Volvo Logistics. MSc Thesis, Department of Technology Management and Economics Chalmers University of Technology, Göteborg, Sweden, 2012.
[31] Development of Decision Making Systems. "Data Science". https://www.ronaldvanloon.com (07.12.2019).

[32] Capacent AB-MS. "Power BI Dataflows-Data Warehousing Made Simple?". https://capacent.com/sv/about/news/2019/microsoftpower-bidataflows-data-warehousing-made-simple (14.12.2019).

[33] Ferrari A, Russo M. Analyzing Data with Microsoft Power BI and Power Pivot for Excel. New York, USA, Microsoft Press, 2017.

[34] Salem, R. Abdo, A. "Fixing rules for data cleaning based on conditional functional dependency". Future Computing and Informatics Journal, 1(1), 1-2, 2016.

[35] Ferrari A, Russo M. The Definitive Guide to DAX: Business intelligence with Microsoft Excel, SQL Server Analysis Services, and Power BI. New York, USA, Microsoft Press, 2015.

[36] Doherty R, Sorenson P. "Keeping users in the flow: mapping system responsiveness with user experience". Procedia Manufacturing, 3(1), 4384-4391, 2015.

[37] Erdal M. Satınalma ve Tedarik Zinciri Yönetimi. 3. baskı. İstanbul, Türkiye, Beta, 2014.

[38] Riggins F, Klamm, B. "Data governance case at KrauseMcMahon LLP in an era of self-service BI and Big Data". Journal of Accounting Education, 38(1), 23-36, 2017.

[39] Rasmussen N, Chen CY, Bansal, M. Business Dashboards A Visual Catalog for Design and Deployment. New Jersey, USA, Wiley, 2009.

[40] Rainardi, V. Building a Data Warehouse: With Examples in SQL Server, New York, USA, Apress, 2008.

[41] Allen, S. Terry, E. Beginning Relational Data Modeling. New York, USA, Apress, 2005. 